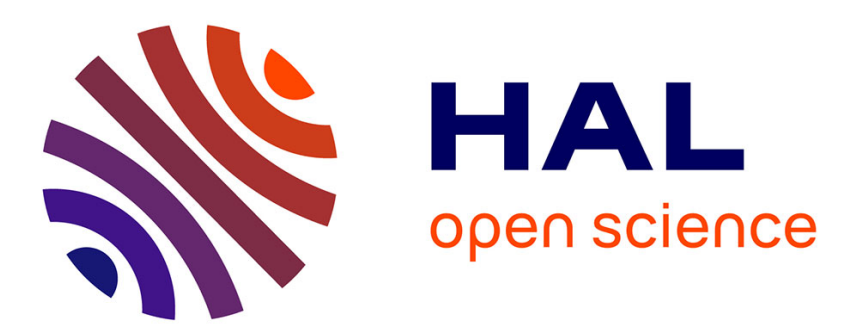

\title{
Competitive biosorption of heavy metals from aqueous solutions onto Streptomyces rimosus
}

\author{
Radia Yous, Faroudja Mohellebi, Hakima Cherifi, Abdeltif Amrane
}

\section{To cite this version:}

Radia Yous, Faroudja Mohellebi, Hakima Cherifi, Abdeltif Amrane. Competitive biosorption of heavy metals from aqueous solutions onto Streptomyces rimosus. Korean Journal of Chemical Engineering, 2018, 35 (4), pp.890-899. 10.1007/s11814-018-0004-1 . hal-01807071

HAL Id: hal-01807071

https://hal-univ-rennes1.archives-ouvertes.fr/hal-01807071

Submitted on 19 Jun 2018

HAL is a multi-disciplinary open access archive for the deposit and dissemination of scientific research documents, whether they are published or not. The documents may come from teaching and research institutions in France or abroad, or from public or private research centers.
L'archive ouverte pluridisciplinaire HAL, est destinée au dépôt et à la diffusion de documents scientifiques de niveau recherche, publiés ou non, émanant des établissements d'enseignement et de recherche français ou étrangers, des laboratoires publics ou privés. 


\title{
Competitive biosorption of heavy metals from aqueous solutions onto Streptomyces rimosus
}

\author{
Radia Yous*, Faroudja Mohellebi**, Hakima Cherifi*, ${ }^{*}$, and Abdeltif Amrane*** \\ *Laboratoire des Biomatériaux et des Phénomènes de Transferts LBPT, Université de Médéa, 26000 Médéa, Algérie \\ **Department of Chemical Engineering, National Polytechnic School, 10, Avenue Pasteur, Belfort, El-Harrach, Algiers, Algeria \\ ***Ecole Nationale Supérieure de Chimie de Rennes, CNRS, UMR 6226, 11 allée de Beaulieu, \\ CS 50837, 35708 Rennes Cedex 7, France \\ (Received 9 February 2017 • accepted 9 January 2018)
}

\begin{abstract}
The aim of this study is the simultaneous biosorption of $\mathrm{Cd}^{+2}$ and $\mathrm{Ni}^{+2}$ on a dead biomass, Streptomyces rimosus pretreated with $\mathrm{NaOH}(0,1 \mathrm{M})$. Kinetic tests were carried out for the binary mixture (cadmium-nickel) during 6 hours contact time to ensure that balance was reached. The amounts adsorbed at equilibrium were $22.8 \mathrm{mg} \mathrm{Ni}^{2+} / \mathrm{g}$ and $9.86 \mathrm{mg} \mathrm{Cd}^{2+} / \mathrm{g}$ biomass, respectively. The biosorption depends mainly by some parameters, such as the $\mathrm{pH}$, the initial concentration of metal and the initial concentration of biomass. The isotherm of adsorption according to two models, Langmuir and Freundlich, was carried out in our study. The results of the kinetics of adsorption show that the experimental values are well represented by the kinetic model of pseudo-second order. This enables us to determine the behavior of these adsorbents with respect to a real industrial effluent.
\end{abstract}

Keywords: Streptomyces rimosus, Cadmium, Nickel, Wastewater Treatment, Batch Biosorption

\section{INTRODUCTION}

Water pollution by heavy metals is causing a great unquiet at present. Indeed, heavy metals, including cadmium and nickel, pose a serious public health problem. They are toxic even at low concentrations particularly in the range and tend to accumulate throughout the food chain [1-3].

Industry is responsible for almost all releases of heavy metals in water. The need to reduce those emissions makes use of processing techniques such as precipitation, electrolysis, ion exchange, whose major drawback is being relatively expensive [4].

The evolution of regulations on industrial emissions and economic considerations has therefore motivated further research into the treatment of industrial waste. For twenty years, various researchers have shown that organic materials such as biomass are able to bind heavy metals by biosorption [5-7].

Some filamentous fungi and some other micro-organisms such as bacteria, algae and yeasts have the ability to sequester metal cations in aqueous solution, and, this, through the special composition of their walls $[8,9]$.

Some industrial plants produce compounds through biochemicals, such as producers of enzymes, organic acids, antibiotics or vitamins. The procedures used in obtaining these compounds mentioned above, discharge sludge mycelium. It is therefore particularly appropriate to develop an economical process that uses these products to perform under the depollution of industrial water loaded with various heavy metals.

\footnotetext{
${ }^{\dagger}$ To whom correspondence should be addressed.

E-mail: ha_cherifi@yahoo.fr
}

Pollution by cadmium and nickel usually comes from several industrial processes such as electroplating, plastics manufacturing, nickel-cadmium batteries, fertilizers, pigments, mining and metallurgical processing [10-12]. In general, these two metals are not encountered separately but together as a mixture in the wastewater of these industries.

The biosorption of cadmium and nickel taken separately on Streptomyces rimosus was studied by Selatnia et al. $[13,14]$. However, till now the biosorption of their mixture was not sufficiently studied as stated by Aksu and Donmez [15]. So, in this work the competitive sorption of $\mathrm{Cd}^{2+}$ and $\mathrm{Ni}^{2+}$ ions present in the same mixture was investigated on Streptomyces rimosus to collect more information on the biosorption of these two pollutants.

Streptomyces rimosus produces about two-thirds of all known antibiotics. The abundance and structural diversity of antibiotic synthesized by these bacteria are not found in any other bacterial genus [16].

The process of extraction of oxytetracycline from fermentation broth is accompanied by several phases of treatment and the formation of many by-products. Large amounts of mycelium of Streptomyces rimosus biomass are produced by fermentation [18]. For instance, the antibiotic complex of Médéa, Algeria (SAIDAL) produced 4 to 5 tons by fermentation.

Our choice was made on this biomass for the following reasons [19]: (a) The biomass has a filamentous morphology, which facilitates the formation of splash allowing their separation from the aqueous phase; (b) The biomass can be regenerated, which allows its re-use; (c) The rigid cellular wall of these gram-positive bacteria contains many negative radicals which can be used as active sites; (d) The active sites present an affinity for the divalent metal cations; and (e) The biomass is available in great quantity and at a 


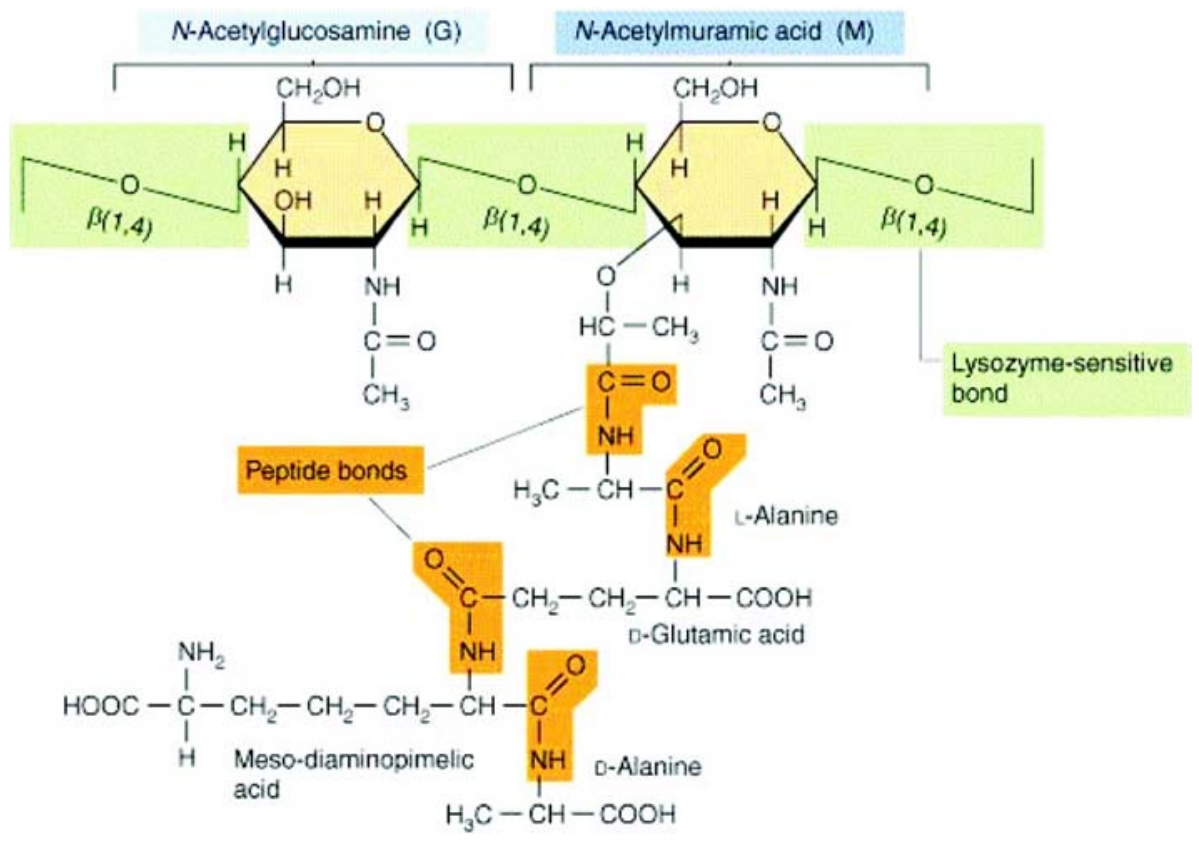

Fig. 1. Structure of the peptidoglycan [15].

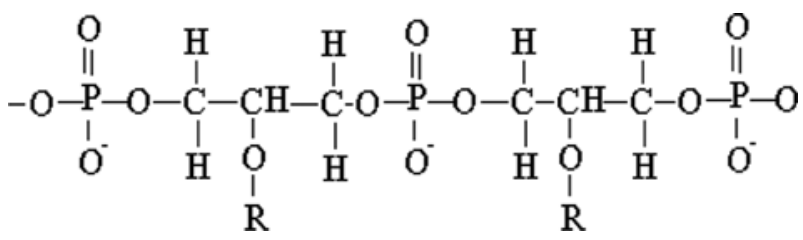

Fig. 2. Chemical structure of the teichoic acid [15].

cheap rate.

The cellular wall of the gram-positive bacteria, Streptomyces rimosus is the seat of the phenomenon of biosorption. This wall consists of a polymer, peptidoglycan, and teichoic acid.

Peptidoglycan (Fig. 1) is the basic structural element. It is constituted of a glucosamine peptide comprising a molecule of NR acetylglucosamine (NAG) and a molecule of acid acetylmuramic (RAM) connected between them by a $\beta$-glucosidic connection. Acid acetyl muramic (RAM) is a short peptide chain of four aminoacids, constituted of two alanines (Ala), a glutamic acid (Lime) and a diaminopimelic acid L.L (DAP) [15].

Teichoic acid (Fig. 2) represents the second component of the gram-positive bacteria. Because of its ionic property, the teichoc acid offers active sites which adsorb the metal cations. It plays therefore a prominent role in the mechanism of biosorption [15].

\section{ADSORPTION ISOTHERMS AND DIFFUSION MODELS}

\section{Adsorption Isotherms}

The Langmuir and Freundlich are the most frequently used isotherm models in the literature describing the non-linear equilibrium between adsorbed pollutant on the cells and pollutant in solution at a constant temperature [19].
The Langmuir model [20] corresponds to the following equation (Eq. (1)):

$$
\mathrm{q}_{e}=\mathrm{q}_{m} \frac{\mathrm{b} \cdot \mathrm{C}_{e}}{1+\mathrm{bC}_{e}}
$$

This equation can be simplified as:

$$
\frac{\mathrm{C}_{e}}{\mathrm{q}_{e}}=\frac{1}{\mathrm{q}_{m} \cdot \mathrm{b}}+\frac{\mathrm{C}_{e}}{\mathrm{q}_{m}}
$$

The Freundlich [21] model equation is of the form:

$$
\mathrm{q}_{e}=\mathrm{k}_{F} \cdot \mathrm{C}_{e}^{1 / n}
$$

$\mathrm{K}_{F}$ and $\mathrm{n}$ are constants characteristic of the Freundlich equation. Their determination is done using the following equation:

$$
\log \mathrm{q}_{e}=\log \mathrm{K}_{F}+\frac{1}{\mathrm{n}} \log \mathrm{C}_{e}
$$

\section{Kinetics of Adsorption}

The study of the kinetics is thus of great importance to define the effectiveness of a process. During the liquid-solid reactions, four stages can be quoted and applied to the recovery of cadmium and nickel as shown in Fig. 2 [22-24].

Step 1. Transfer of the cadmium or the nickel of the mass of the fluid towards film surrounding surface of the particle of biomass;

Step 2. Transfer of the cadmium or the nickel of film towards the surface of the particle;

Step 3. Transfer of the cadmium or the nickel of the surface of the particle towards the sites inside the particle;

Step 4. Fixing the metal ion on the active sites by mechanisms of complexation, adsorption and precipitation.

Generally, the second phase describes the transfer resistance through the film; the third step is related to the model of intra particular diffusion. The first and the fourth step are fast and hence not 

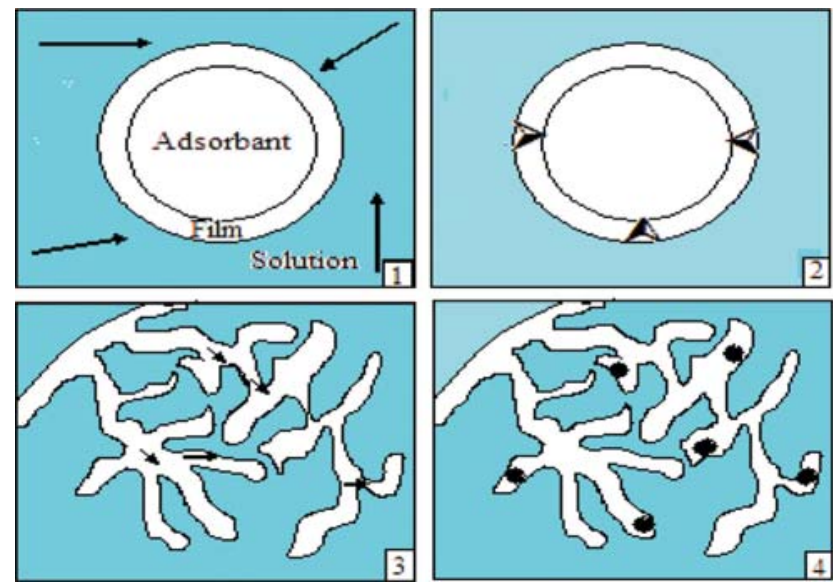

Fig. 3. Representation of the biosorption stages [22-24].

limiting stages. In this study, we determined the limiting step in the total process of adsorption [25-29].

2-1. Model of External Mass Transfer

The concentration at the surface of a material depends on the diffusion through the boundary layer. The model proposed by Weber and Morris [30], Mc Kay and Poots [31] and McKay et al. [24] was chosen. This model assumes that the concentration of the metal surface $\left(\mathrm{C}_{s}\right)$ at $\mathrm{t}=0$ is negligible, and thus internal diffusion is negligible. The coefficient of external mass transfer is then defined by the following equation:

$$
\frac{\mathrm{dC}}{\mathrm{dt}}=-\beta \cdot \mathrm{S} \cdot\left(\mathrm{C}-\mathrm{C}_{s}\right)
$$

With S: The specific surface of the particle per unit volume of solution $\left(\mathrm{m}^{-1}\right)$. It is calculated from the following equation:

$$
\mathrm{S}=\frac{6 \mathrm{C}_{b}}{\mathrm{~d}_{p} \cdot \rho_{a p p}}
$$

\section{2-2. Model of Intra-particular Mass Transfer}

For a porous grain, size ions lower than those of the pores can migrate inside the grain (step 3). Transport will be thus depending on the molecular diffusivity of the ions and the characteristics of the pores. The diffusion obeys Fick's second law.

In this work, the models chosen refer to theories developed by Weber and Morris [30] and Urano and Tachikawa [32]. From this model the internal diffusion coefficient is calculated from the following equation:

$$
\mathrm{q}=\mathrm{K}_{w} \mathrm{t}^{0,5}
$$

With:

$$
\mathrm{K}_{w}=\left(\frac{12 \mathrm{q}_{e}}{\mathrm{~d}_{p}}\right)\left(\frac{\mathrm{D}_{w}}{\pi}\right)^{0,5}
$$

The diffusion coefficient is calculated by determining the slope behind the curve $\left(\mathrm{q}_{e}\right)$ versus time $(\mathrm{t})$. The adsorption kinetics is modeled by Eq. (9), developed by Urano and Tachikawa [32]:

$$
-\log _{10}\left[1-\left(\frac{\mathrm{q}}{\mathrm{q}_{e}}\right)^{2}\right]=\frac{4 \pi^{2} \mathrm{D}_{u} \mathrm{t}}{2.3 \mathrm{~d}_{p}^{2}}
$$

\section{2-3. Kinetics Models}

The term of the first-order kinetics was proposed by Lagergren [33]. This kinetic is usually expressed by the following equation:

$$
-\log _{10}\left[\frac{\left(\mathrm{q}_{e}-\mathrm{q}\right)}{\mathrm{q}_{e}}\right]=\frac{\mathrm{k}_{1}}{2.3} \mathrm{t}
$$

The kinetics of second order was expressed by Ho and McKay [34] and Aksu [35] in the case of biosorption by Eq. (11).

$$
\left[\frac{1}{\left(\mathrm{q}_{e}-\mathrm{q}\right)}\right]=\left[\frac{1}{\mathrm{q}_{e}}\right]+\mathrm{k}_{2} \mathrm{t}
$$

\section{MATERIALS AND METHODS}

A Streptomyces rimosus biomass is a byproduct of an antibiotic production that was collected after fermentation. For experimental use, the biomass was washed with deionized water several times and dried at $50{ }^{\circ} \mathrm{C}$ during $24 \mathrm{~h}$. After this, the biomass was boiled in $\mathrm{NaOH} 0.1 \mathrm{~mol} / \mathrm{L}$ for $15 \mathrm{~min}$. It was then washed with generous amounts of deionized water as long as the $\mathrm{pH}$ of the washing solution was near the neutral range. After washing, the biomass was dried at $50{ }^{\circ} \mathrm{C}$ for $24 \mathrm{~h}$ and ground to a granulated form by a chopper and sieved to obtain various particle sizes from 50 to $160 \mu \mathrm{m}$.

Stock solutions $(2,000 \mathrm{mg} / \mathrm{L})$ of the nickel and cadmium ions under study were prepared by dissolving an appropriate weight of pure salt $\left(\mathrm{NiCl}_{2}, 6 \mathrm{H}_{2} \mathrm{O}\right.$ or $\left.\mathrm{CdCl}_{2}, 5 \mathrm{H}_{2} \mathrm{O}\right)$ in the desired volume of de-ionized water. The stock solution was successively diluted with de-ionized water to obtain the desired test concentration of metal ion. All the chemicals used in the study were of analytical reagent grade and all experiments were at room temperature $\left(24 \pm 1^{\circ} \mathrm{C}\right)$. The batch mode was used to study the adsorption of $\mathrm{Ni}(\mathrm{II})$ and Cd(II) on Streptomyces rimosus.

Sorption studies were conducted in a number of plugged Pyrex glasses Erlenmeyer containing a definite volume $(500 \mathrm{~mL}$ in each case) of solutions of the metal ion with initial concentration of $100 \mathrm{mg} / \mathrm{L}$. The conical flasks were then placed in a thermostatic shaker bath (Memmert Type WB-14 equipped with a SV 1422 temperature controller) and were shaken at $250 \mathrm{rpm}$ for 3 hours. All the experiments were carried out in duplicate and the average of the values was used for further calculations.

The concentrations of metals at equilibrium were determined by atomic absorption spectrometry at a wavelength of $228.8 \mathrm{~nm}$ for cadmium and $232 \mathrm{~nm}$ for nickel.

Given the small size of the adsorbent used $(160 \mu \mathrm{m})$ and the fact that the operation was conducted with sufficient agitation to ensure good homogeneity of the system, it can be assumed that the mass ratio of adsorbent to volume of solution remained constant throughout the operation. All experimental results were generally expressed as adsorption capacity "q" which we defined as follows:

$$
\mathrm{q}=\left(\frac{\mathrm{C}_{0}-\mathrm{C}}{\mathrm{m}}\right) \mathrm{V}
$$

Posing $\mathrm{C}_{b}=\mathrm{m} / \mathrm{v}$, Eq. (13) becomes:

$$
\mathrm{q}=\frac{\mathrm{C}_{0}-\mathrm{C}}{\mathrm{C}_{b}}
$$




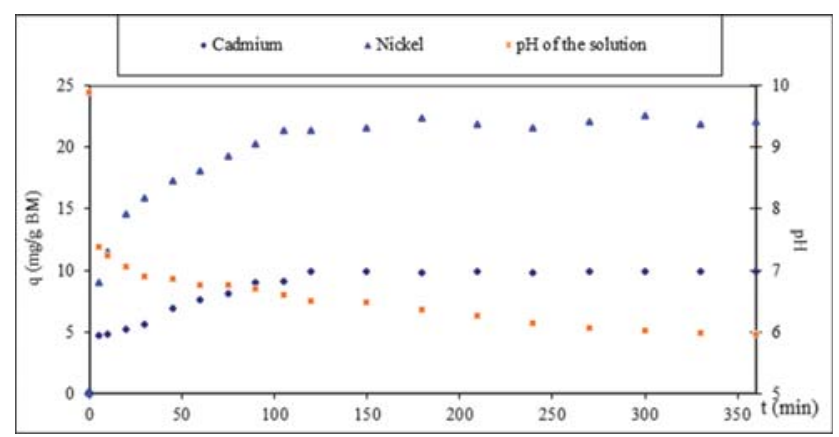

Fig. 4. Evolution of $\mathrm{pH}$ and the capacity of biosorption of $\mathrm{Cd}^{+2}$ and $\mathrm{Ni}^{2+}$ simultaneously with time.

The elimination rate $\mathrm{E}$ was defined by the equation:

$$
\mathrm{E}=\left(\frac{\mathrm{C}_{0}-\mathrm{C}}{\mathrm{C}_{0}}\right) \cdot 100
$$

\section{RESULTS AND DISCUSSION}

\section{Biosorption Kinetics}

The kinetic study of the biosorption of nickel and cadmium simultaneously biomass treated with $\mathrm{NaOH}(0.1 \mathrm{~N})$, is the determination of residual concentrations of ions $\mathrm{Ni}^{+2}$ and $\mathrm{Cd}^{+2}$ in solutions over time. Fig. 4 represents the kinetics or biosorption of cadmium and nickel on biomass. Given the intimate phenomena that can occur between the biosorbent and the solution, it seemed interesting to follow the $\mathrm{pH}$ evolution during the biosorption phenomenon, which was therefore displayed on the figure.

The fast kinetics is due to the high reactivity of the surface of the biomass. Indeed, the biosorption of metals depends strongly on the protonation or deproteinized functional groups (carboxylic, phosphate, hydroxyl amines) present on the wall of the biomass [36-38]. Moreover the chemical treatment of the biomass shows that the ion exchange between $\mathrm{Na}^{+}$ions and $\mathrm{Cd}^{+2}$ and $\mathrm{Ni}^{+2}$ is easier than the ion exchange between $\mathrm{H}^{+}$ions and $\mathrm{Cd}^{+2}$ and $\mathrm{Ni}^{+2}$.

After two hours of contact the adsorbed quantity of nickel (22.09 $\mathrm{mg} \mathrm{Ni}^{2+} / \mathrm{g}$ of biomass) was remarkably higher than that of cadmium (9.83 $\mathrm{mg} \mathrm{Cd}^{2+} / \mathrm{g}$ of biomass). The observed difference could be due to the high electronegativity of $\mathrm{Ni}$ atoms compared to that of $\mathrm{Cd}$ ones, revealing an easy cationic exchange of $\mathrm{Na}^{+} / \mathrm{Ni}^{2+}$ than that of $\mathrm{Na}^{+} / \mathrm{Cd}^{2+}[39]$.

Concerning the $\mathrm{pH}$, the decrease observed may be attributed to the release of $\mathrm{H}^{+}$functional groups present on the wall of the biomass.

\section{Kinetics Models}

The determination of the kinetics of adsorption of ions $\mathrm{Cd}^{2+}$ and $\mathrm{Ni}^{2+}$ makes it possible to calculate the rates constants of adsorption $[40,41]$.

\section{2-1. Determination of Rate Constants of Adsorption}

To determine the constant rates of adsorption, the order of the reaction should be first determined, by plotting the curve representing $\log \left(\mathrm{q}_{e} /\left(\mathrm{q}_{e}-\mathrm{q}\right)\right)$ according to the time as shown in Fig. 5.

The shape of these curves suggests that the variation of the Log $\left(\mathrm{q}_{e} /\left(\mathrm{q}_{e}-\mathrm{q}\right)\right)$ according to time is not linear. Therefore, adsorption

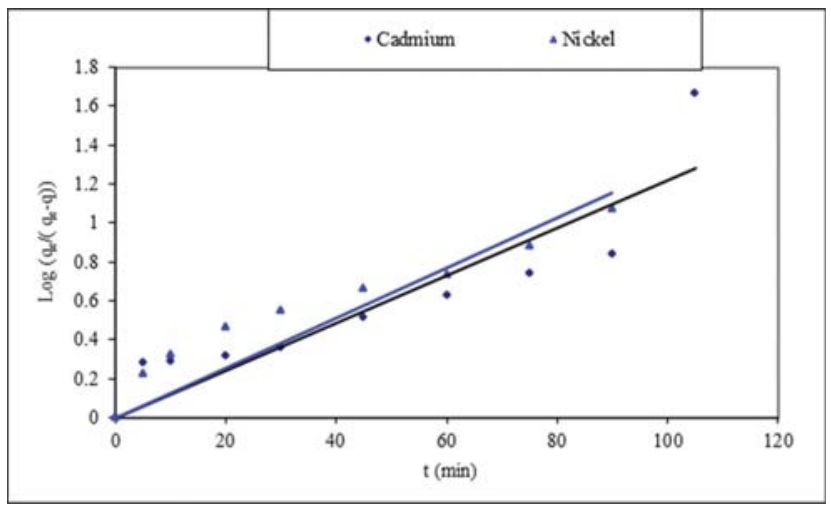

Fig. 5. Constant first order speed of biosorption of the mixture $\mathrm{Cd}^{+2}$ and $\mathrm{Ni}^{+2}$ for a treated biomass.

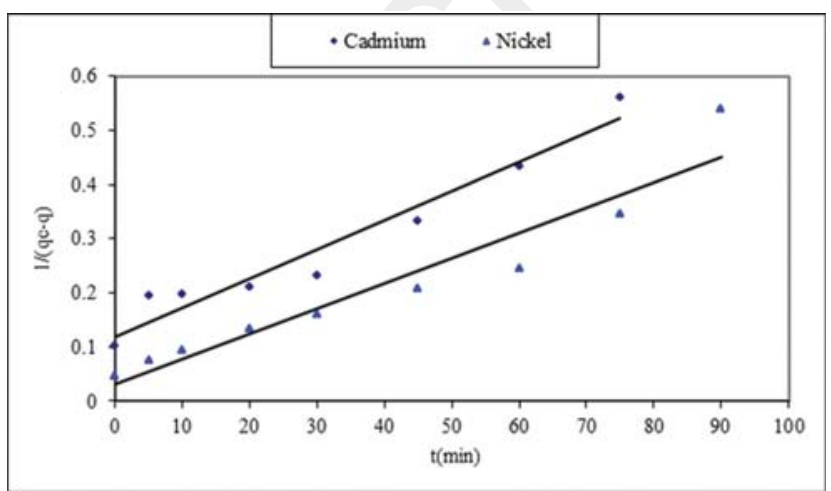

Fig. 6. Constant second-order speed of biosorption of the mixture $\mathrm{Cd}^{+2}$ and $\mathrm{Ni}^{+2}$.

Table 1. Values of rate constants of biosorption mixture of $\mathrm{Cd}^{2+}$ and $\mathrm{Ni}^{2+}$

\begin{tabular}{cccccc}
\hline \hline & \multicolumn{2}{c}{ First order reaction } & & \multicolumn{2}{c}{ Second order reaction } \\
\cline { 2 - 3 } \cline { 5 - 6 } & $\mathrm{K}_{1}\left(\mathrm{~s}^{-1}\right)$ & $\mathrm{R}^{2}$ & & $\mathrm{~K}_{2}(\mathrm{~g} / \mathrm{mg} \cdot \mathrm{s})$ & $\mathrm{R}^{2}$ \\
\hline $\mathrm{Cd}^{+2}$ & 0.0122 & 0.8206 & & 0.0054 & 0.9493 \\
$\mathrm{Ni}^{+2}$ & 0.0129 & 0.8252 & & 0.0046 & 0,9199 \\
\hline
\end{tabular}

can be second-order and the values of the constants speeds of nickel and cadmium are given by calculating the slopes of the righthand sides accounting for $1 /\left(\mathrm{q}_{e}-\mathrm{q}\right)$ according to time. These straight lines are schematized on Fig. 6.

From this table we can conclude that the kinetics adsorption ions $\mathrm{Ni}^{2+}$ and $\mathrm{Cd}^{2+}$ on biomass followed a second order. The pseudosecond-order expression was successfully applied to the adsorption of metal ions from aqueous solutions. A theoretical analysis of the pseudo-second-order model indicated that when the initial concentration of solute is low, the adsorption process obeys the pseudosecond-order model [42]. Conversely pseudo-first-order model can be applied to higher initial concentrations. Our results are in accordance with that stated in Azizian [42]. The rate constant of the pseudo-second order model is a complex function of the initial concentration of the solute. For this, we have introduced a new parameter h described by Eq. (15) [43]: 


$$
\mathrm{h}=\mathrm{K}_{2} \cdot \mathrm{q}_{\mathrm{e}}^{2}
$$

Where $\mathrm{h}$ is the initial adsorption rate $(\mathrm{mg} / \mathrm{g} \cdot \mathrm{s})$ as $\mathrm{qt} / \mathrm{t}$ approaches 0 .

The calculation of $\mathrm{h}$ for the ions of $\mathrm{Ni}^{2+}$ gave a value of $2.24 \mathrm{mg} /$ g.s, while for the Cd ions, the value of $\mathrm{h} 0.53 \mathrm{mg} / \mathrm{g} \cdot \mathrm{s}$; These values showed that there was a competition between nickel and cadmium during the biosorption and that the $\mathrm{Ni}$ was first adsorbed.

\section{Diffusion Model}

3-1. Determination of the Coefficient of External Mass Transfer

To estimate the influence of external resistance, we determined the coefficient of external mass transfer by making the assumption that this stage of the process is not negligible, and it was calculated at the first moments of liquid solid contact (slope in the beginning when $t_{X \rightarrow 0}$ ). Indeed, this assumption is justified by the fact that at the moment $t_{Y \rightarrow 0}$, only the external mass transfer would have begun.

The values of the coefficients of external mass transfer $\beta$ are given by determining the slopes at the origin of the curved representatives report $\mathrm{C} / \mathrm{C}_{0}$ according to time. Fig. 7 illustrates these results. This last being emphasized by the following equation $[17,24,41]$ :

$$
\left(\frac{\mathrm{dC} / \mathrm{C}_{0}}{\mathrm{dt}}\right)_{t \rightarrow 0}=-\beta \cdot \mathrm{S}
$$

The linear part of the variation of $\mathrm{C} / \mathrm{C}_{0}$ according to time is rep-

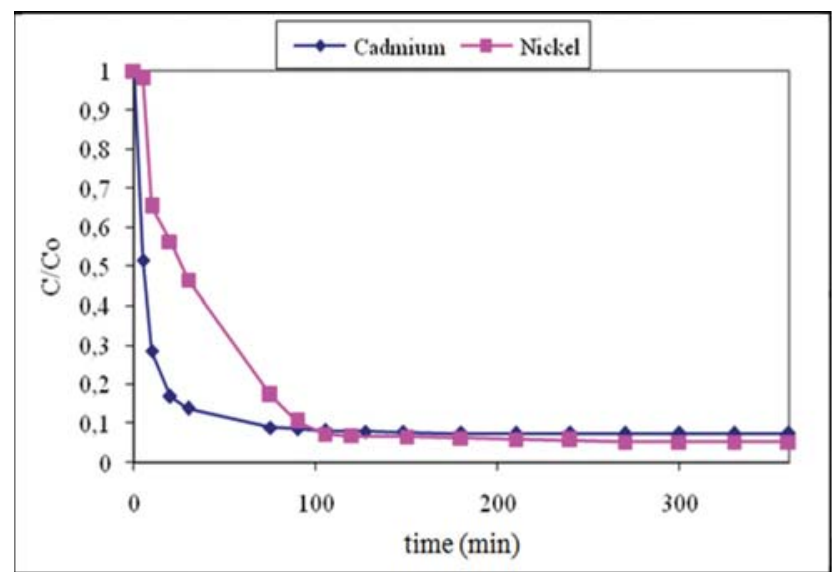

Fig. 7. Variation of $\mathrm{C} / \mathrm{C}_{0}$ according to time.

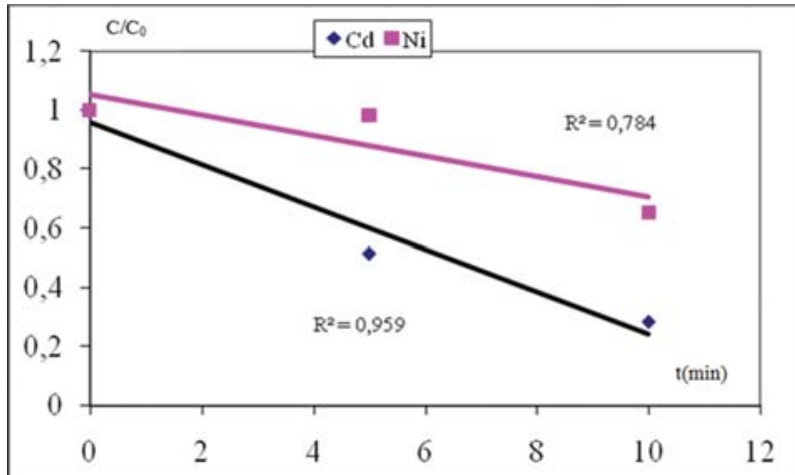

Fig. 8. Linear part of the variation of $\mathrm{C} / \mathrm{C}_{0}$ according to time.
Table 2. Values of the coefficients of external mass transfer

\begin{tabular}{cl}
\hline \hline & $\beta(\mathrm{m} / \mathrm{s})$ \\
\hline $\mathrm{Cd}^{+2}$ & $6.3710^{-5}$ \\
$\mathrm{Ni}^{+2}$ & $1.210^{-4}$ \\
\hline
\end{tabular}

resented by Fig. 8 .

The coefficient of total external transfer $(\beta)$, is calculated from the slopes of the right-hand side represented on Fig. 8 .

Table 2 gathers the values of the coefficient of external mass transfer of metals.

3-2. Determination of the Coefficient of Internal Mass Transfer

In the same way to estimate of the coefficients of internal diffusion, we neglected resistance to the external mass transfer and the kinetics of adsorption. According to the stirring velocity chosen, only the internal diffusion controls the process [44]. In this case, the mathematical equations relating to the diffusion in a sphere can be applied. From this, two models describing the internal diffusion, the model of Weber and Morris [30] and that of Urano and Tachikawa [32] were considered.

For the application of the model Weber and Morris, we traced $\mathrm{q} / \mathrm{q}_{e}$ according to $\mathrm{t}^{1 / 2}$. The slope of the right-hand side in the beginning obtained allowed determining the value of the internal coefficient of diffusion. Fig. 9 illustrates these results.

For the model of Urano and Tachikawa [23], the internal coeffi-

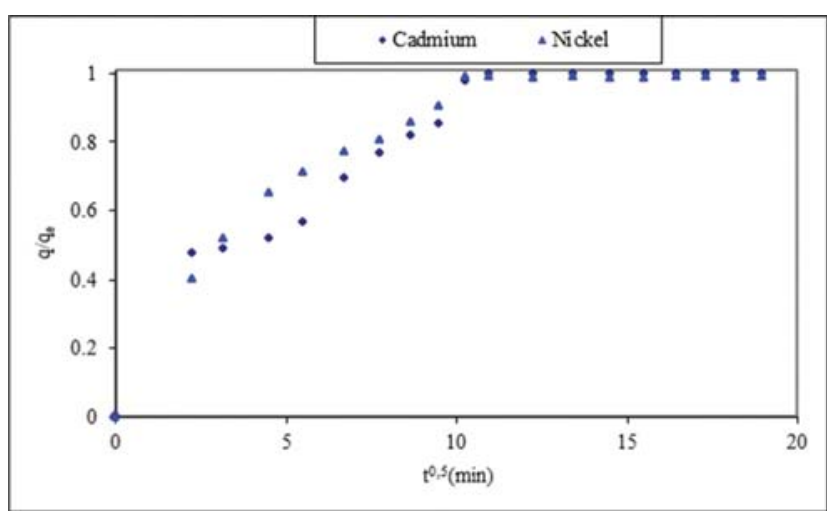

Fig. 9. Variation of $q / q_{e}$ according to time.

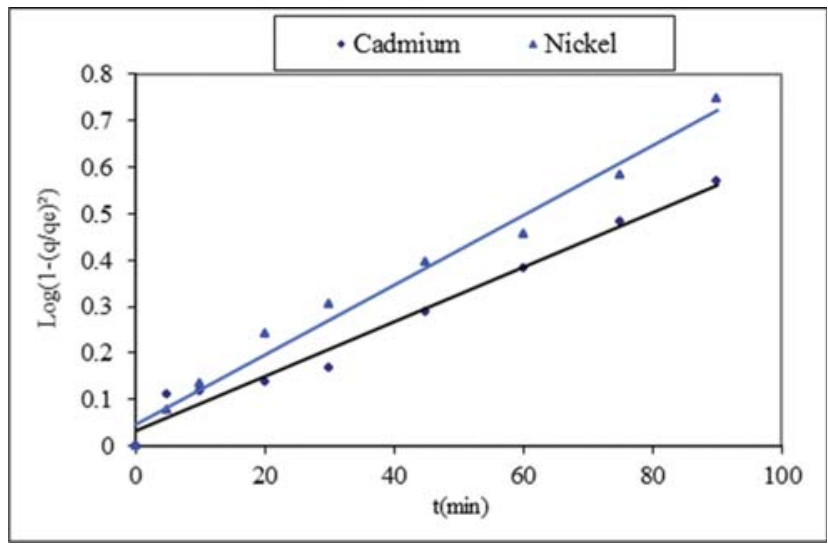

Fig. 10. Variation of $\log 10\left(1-\left(q / q_{e}\right)\right)$ according to time. 
Table 3. Values of the coefficients of internal diffusion

\begin{tabular}{ccc}
\hline \hline & $\mathrm{D}_{w}\left(\mathrm{~m}^{2} / \mathrm{s}\right)$ & $\mathrm{D}_{u}\left(\mathrm{~m}^{2} / \mathrm{s}\right)$ \\
\hline $\mathrm{Cd}^{+2}$ & $9.910^{-12}$ & $3.3610^{-12}$ \\
$\mathrm{Ni}^{+2}$ & $7.1210^{-12}$ & $3.4310^{-12}$ \\
\hline
\end{tabular}

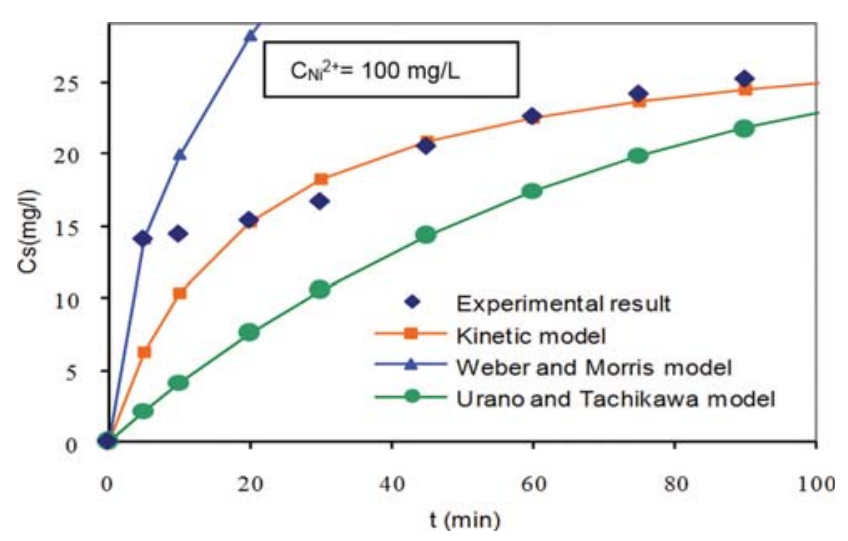

Fig. 11. Diffusion and kinetics models adsorption of $\mathrm{Ni}^{2+}$ on the biomass treated.

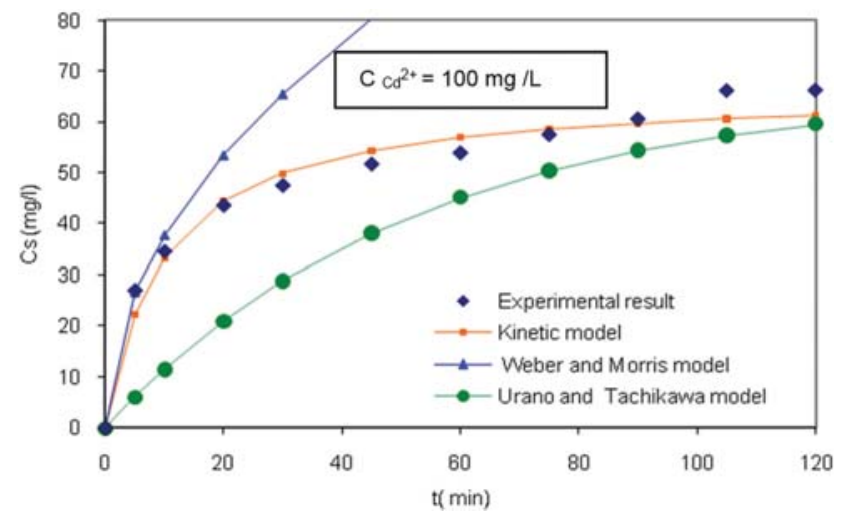

Fig. 12. Diffusion and kinetics models adsorption of $\mathrm{Cd}^{2+}$ on the biomass treated.

cient of diffusion of the east obtained by the slope of the linear part $\log 10\left(1-\left(\mathrm{q} / \mathrm{q}_{e}\right)\right)$ according to time, as shown in Fig. 10 .

Table 3 includes values for the internal diffusion coefficients $D_{w}$ and $\mathrm{D}_{u}$. This table shows that the resistance to external mass transfer was negligible compared to internal distribution. So, we must compare the experimental results with those calculated by the kinetic and diffusional models.

This comparative study is illustrated in Figs. 11 and 12. From these figures, it can be concluded that the kinetic model described accurately the experimental results, and hence this step limits the rate of adsorption.

\section{Influence of Initial $\mathrm{pH}$ on the Biosorption of the Cadmium- nickel Mixture}

Former studies on the biosorption of heavy metals show that the $\mathrm{pH}$ is an important parameter affecting the process of biosorption $[45,46]$. This fact can be explained by the strong relation between the biosorption and the number of negative charges on the surface of the biomass, which themselves are in relation to the func-

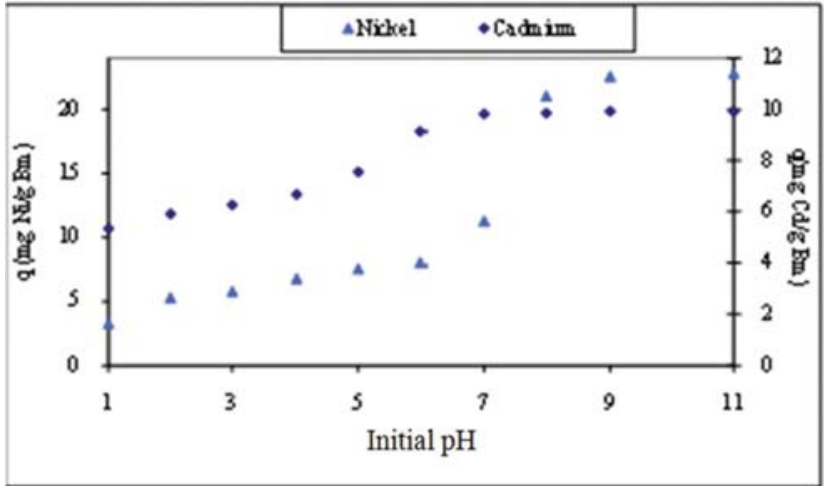

Fig. 13. Influence of the initial $\mathrm{pH}$ of the solution on the capacity of biosorption of the mixture $\mathrm{Cd}^{+2}$ and $\mathrm{Ni}^{+2}$.

tional groupings. The ionic shape of metal in solution and the electric charge of the biomass depend on the $\mathrm{pH}$ of the solution. The biosorption of heavy metals can be the effect of the ionization and the negative charge of the functional groupings being useful like sites of fixing of heavy metals.

The influence of the concentration of hydrogen ion on the biosorption of the mixture $\mathrm{Cd}^{+2}$ and $\mathrm{Ni}^{+2}$ was studied by changing the $\mathrm{pH}$ of the solution into metal $\mathrm{pH}$ of the solution $\mathrm{pH}=1$ to 11 . The experimental results are represented on Fig. 13.

For nickel, one notes the increase in the capacity of adsorption with the increase in the $\mathrm{pH}$ to reach a maximum of adsorption for a basic ( $\mathrm{pH}=12)$; it was similar for cadmium, except that the capacity of adsorption was less marked.

The low capacity of adsorption of cadmium and nickel for very acid $\mathrm{pH}(<5)$ can be explained by the quantity of existing $\mathrm{H}^{+}$ions in the solution; these ions limit the release of the $\mathrm{H}^{+}$ions of the functional groupings $(\mathrm{COOH}$ and $\mathrm{OH})$, which cannot thus fix the metals cations. For the free doublets of the $\left(\overline{\mathrm{N}} \mathrm{H}_{2}\right)$ groups, there is a competition between the $\mathrm{H}+$ protons and the cations $\mathrm{Cd}^{+2}$ and $\mathrm{Ni}^{+2}$, which makes the biosorption slow. The more the $\mathrm{pH}$ of the solution increased, the more the probability of adsorption of the metal cations increased. It can be noted that for $\mathrm{pH}<5$ the retention of the metal ions was low. The capacities of biosorption were improved for $\mathrm{pH}>5[35,36,39]$.

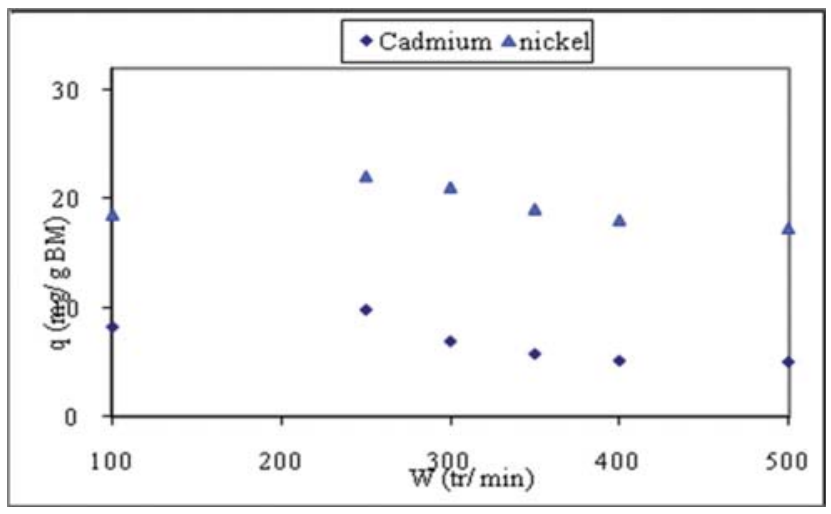

Fig. 14. The influence of the stirring velocity on the biosorption of $\mathrm{Cd}^{+2}$ and $\mathrm{Ni}^{+2}$. 


\section{Influence of the Stirring Velocity}

To locate the influence of the stirring velocity on the capacity of adsorption of the mixture $\mathrm{Cd}^{+2} \mathrm{Ni}^{+2}$, the stirring velocity between 100 and $500 \mathrm{rpm}$ can be varied. The evolution of the capacity of adsorption according to the stirring velocity for the mixture $\mathrm{Cd}^{+2}$ and $\mathrm{Ni}^{+2}$ is represented in Fig. 14 .

The simultaneous presence of the ions $\mathrm{Cd}^{+2}$ and $\mathrm{Ni}^{+2}$ gives the best capacity of fixing to $250 \mathrm{tr} / \mathrm{min}$. For speeds lower than 250 rpm, the low capacities of fixing can be explained by the decantation of the powders of adsorbents, which makes resistance diffusion around the solid important. While for strong stirring velocities, the vortex phenomena occurred and the suspension was no longer homogeneous, which made adsorption difficult.

\section{Influence of Concentration of Biosorbent}

We studied the influence of the concentration of biosorbent on the capacity of adsorption of the mixture $\mathrm{Cd}^{+2}$ and $\mathrm{Ni}^{+2}$. The results obtained are presented in Fig. 15.

The increase in the concentration in biomass influences positively the rate of elimination of the ions up to a value of $3 \mathrm{~g} / \mathrm{L}$ (Fig. 15). Starting from this optimal concentration in biomass, an improvement of the percentage of the removal of the $\mathrm{Cd}^{+2}$ and $\mathrm{Ni}^{+2}$ ions can be noted. This can be explained by the saturation of the biosorbent.

\section{Influence of the Initial $\mathrm{Cd}^{+2}$ and $\mathrm{Ni}^{+2}$ Concentrations}

To determine the effectiveness of adsorption of the biomass treated

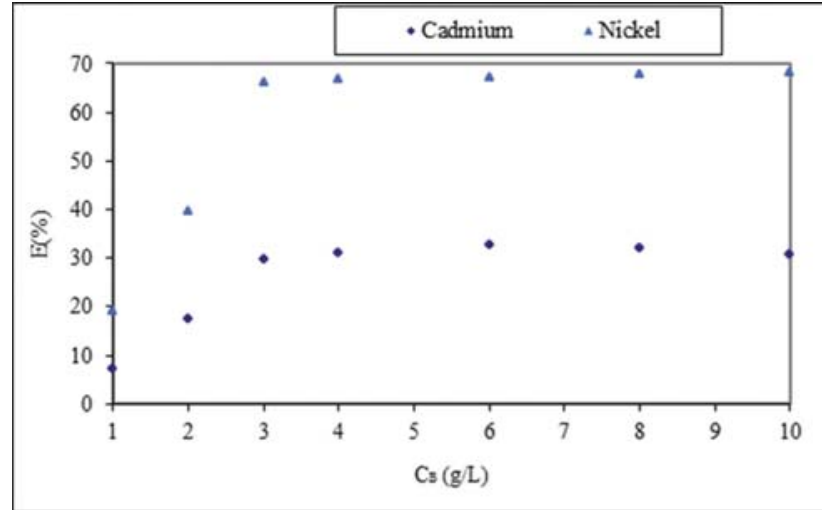

Fig. 15. The influence of the concentration of the biomass treated on the rate of biosorption of the mixture $\mathrm{Cd}^{+2}$ and $\mathrm{Ni}^{+2}$.

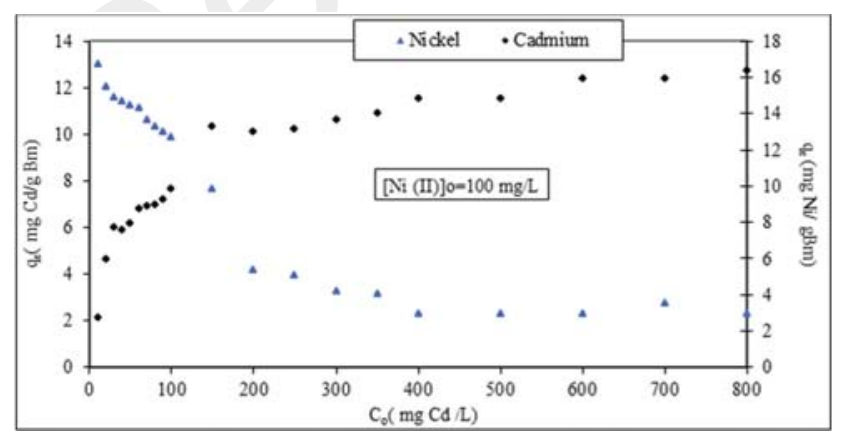

Fig. 16. Influence initial concentration in $\mathrm{Cd}^{+2}$ ions on the capacity of biosorption $\mathrm{Cd}^{+2}$ and $\mathrm{Ni}^{+2}$ of the treated biomass.

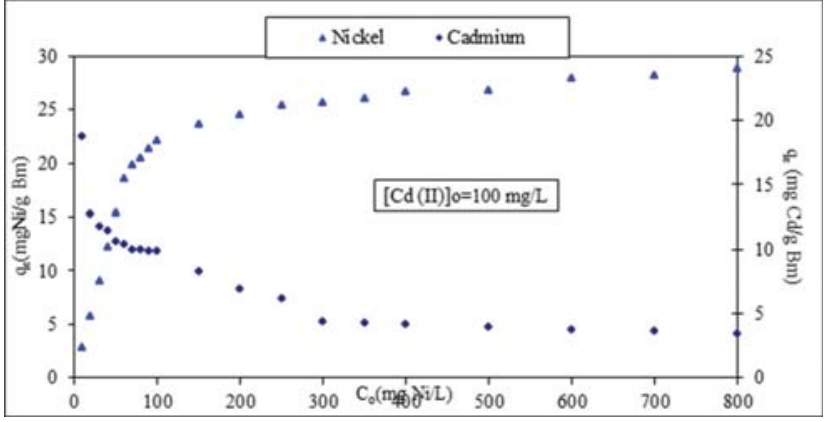

Fig. 17. Variation of the capacity of biosorption of $\mathrm{Cd}^{+2}$ and $\mathrm{Ni}^{+2}$ according to the initial concentrations of $\mathrm{Ni}^{+2}$.

with respect to the cadmium mixture and nickel, the behavior of the biomass according to the various initial metal concentrations was determined. The concentration of the investigated metal was varied in the range 10 to $800 \mathrm{mg} / \mathrm{L}$, while the other was kept at a given concentration (Figs. 16 and 17).

As observed, an increase of the quantity adsorbed according to its initial concentration, followed by a step corresponding to the saturation of the active sites of the biomass.

8. Analysis of the Adsorption Isotherms

The linear form of the Langmuir equation was considered; the results are displayed in Fig. 18.

The Freundlich isotherm is represented by plotting in $\left(\mathrm{q}_{e}\right)$ ver-

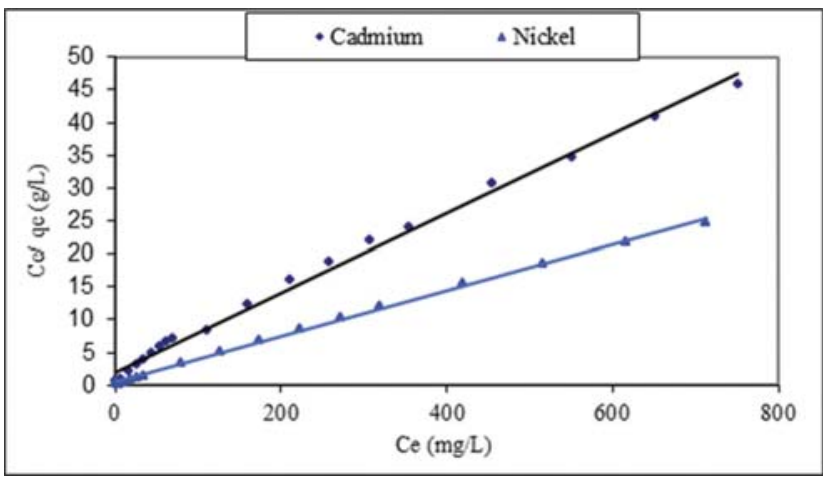

Fig. 18. Langmuir isotherm of the mixture $\mathrm{Ni}^{2+}$ and $\mathrm{Cd}^{2+}$.

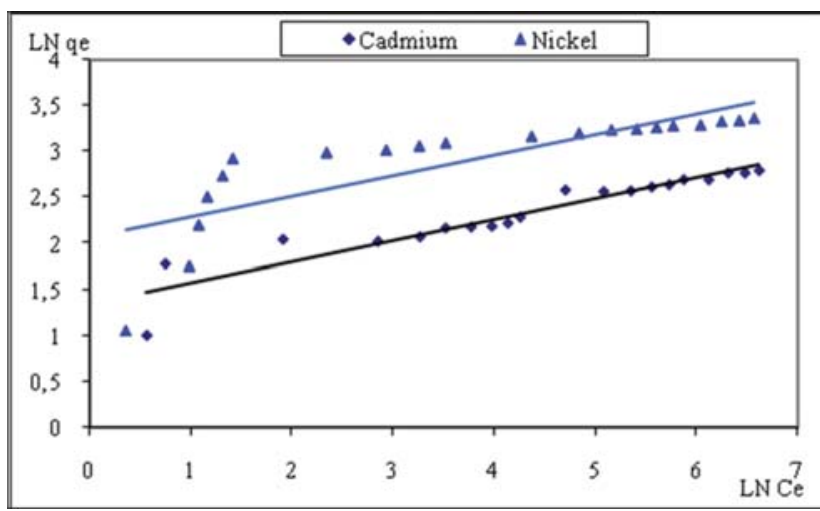

Fig. 19. Freundlich isotherm of the mixture $\mathrm{Ni}^{2+}$ and $\mathrm{Cd}^{2+}$. 
Table 4. Values of model parameters of Langmuir and Freundlich models

\begin{tabular}{cccccccc}
\hline \hline & \multicolumn{3}{c}{ Langmuir } & & \multicolumn{3}{c}{ Freundlich } \\
\cline { 2 - 4 } \cline { 6 - 8 } & $\mathrm{b}$ & $\mathrm{q}_{m}$ & $\mathrm{R}^{2}$ & & $\mathrm{~K}_{F}$ & $\mathrm{n}$ & $\mathrm{R}^{2}$ \\
\hline $\mathrm{Cd}^{2+}$ & 0.03 & 16.5 & 0.994 & & 3.88 & 4.42 & 0.644 \\
$\mathrm{Ni}^{2+}$ & 0.08 & 28.5 & 0.998 & & 7.84 & 4.44 & 0.885 \\
\hline
\end{tabular}

sus $\ln \left(\mathrm{C}_{e}\right)$, as shown in Fig. 19.

The parameters characterizing the models of Langmuir and Freundlich are given in Table 4.

These results, allowed us to establish that the model followed was the Langmuir isotherm model, owing to the higher correlation coefficients obtained if compared to the Freundlich model.

An essential characteristic of the Langmuir isotherm can be expressed in terms of a dimensionless constant called the separation factor and defined by the equation below (Eq. (17)):

$$
\mathrm{R}_{L}=\frac{1}{1+\mathrm{b} \cdot \mathrm{C}_{0}}
$$

where $\mathrm{C}_{0}$ is the initial concentration of the adsorbate $\left(\mathrm{mg} \cdot \mathrm{L}^{-1}\right)$ and b is the Langmuir constant $\left(L \cdot \mathrm{mg}^{-1}\right)$. A separation factor $R_{L}>1$ indicates that the adsorption is unfavorable; if $\mathrm{R}_{L}=1$ the adsorption is said to be linear, adsorption is said to be favorable when $0<\mathrm{R}_{L}<1$. And a zero separation factor $\left(\mathrm{R}_{L}=0\right)$ indicates that adsorption is irreversible [47]. In our case, the values of $R_{L}$ were between 0 and 1 ( 0.25 for cadmium and 0.11 for nickel), which shows favorable adsorption for both metals, but the adsorption of nickel was more intense than that of cadmium on the basis of the lower $\mathrm{R}_{L}$ value for $\mathrm{Ni}$ if compared to that of $\mathrm{Cd}$. From this, in the mixture solution the biosorption of $\mathrm{Ni}$ by Streptomyces rimosus was comparatively more than that of $\mathrm{Cd}$.
The correlation coefficients $\mathrm{R}^{2}$ of the Freundlich model were lower than that of Langmuir model, confirming that the adsorption of heavy metals on Streptomyces rimosus treated with $\mathrm{NaOH}$ follows the Langmuir model rather than Freundlich model.

9. Comparison of $\mathrm{Cd}^{2+}$ and $\mathrm{Ni}^{+2}$ Adsorption Capacity by Different Adsorbents

The maximum adsorption capacities of different adsorbents for the removal of $\mathrm{Cd}^{2+}$ and $\mathrm{Ni}^{+2}$ were compared with extensive reports in the literature; the values of adsorption capacities are shown in Table 5. The experimental data of this present study are comparable to the reported values. Nevertheless, the maximum adsorption capacity $\mathrm{q}_{m}(\mathrm{mg} / \mathrm{g})$ is usually calculated from an adsorption isotherm equation, based on equilibrium data. Also, it can be noticed that modification of the adsorbents could also improve $\mathrm{Cd}^{2+}$ and $\mathrm{Ni}^{+2}$ adsorption capacity.

\section{CONCLUSION}

The present work shows the use of biosorption as a promising method for $\mathrm{Ni}^{2+}$ and $\mathrm{Cd}^{2+}$ removal from waste water. In addition, biomass is a cheap source of biosorbent. If it is available as a waste from other fermentation industries which represents further advantage to the process, regarding to the cumulative costs and simplicity of the technology. The non-living biomass of Streptomyces rimosus was shown to be an efficient biosorbent for $\mathrm{Ni}^{2+}$ and $\mathrm{Cd}^{2+}$ ions with a promising biosorption capacity. The sorption of the mixture $\mathrm{Cd}^{2+}$ and $\mathrm{Ni}^{2+}$ on the biomass treated allows one to conclude that the equilibrium adsorption of ions $\mathrm{Cd}^{+2}$ and $\mathrm{Ni}^{+2}$ is reached after 3 hours. The amounts adsorbed at equilibrium were $22.8 \mathrm{mg}$ $\mathrm{Ni}^{2+} / \mathrm{g}$ and $9.86 \mathrm{mg} \mathrm{Cd}^{2+} / \mathrm{g}$ biomass, respectively. The obtained results also showed that initial $\mathrm{pH}$, stirring velocity, concentration of biosorbent and initial concentration in ions $\mathrm{Cd}^{+2}$ and $\mathrm{Ni}^{+2}$ affected the uptake capacity of the biosorbent.

Table 5. Adsorption capacities of different adsorbents for the removal of $\mathrm{Cd}^{2+}$ and $\mathrm{Ni}^{+2}$ from water

\begin{tabular}{|c|c|c|c|c|}
\hline 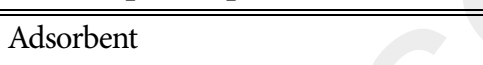 & $\mathrm{Ni}^{+2}(\mathrm{mg} / \mathrm{L})$ & $\mathrm{Cd}^{+2}(\mathrm{mg} / \mathrm{L})$ & $\overline{\mathrm{Q}_{m}(\mathrm{mg} / \mathrm{g})}$ & Source \\
\hline \multirow{3}{*}{ Pseudomonas spp. } & 100 & 1 & 17.96 & {$[448]$} \\
\hline & I & 100 & 14.19 & [48] \\
\hline & 100 & 100 & $\begin{array}{l}7.35 \text { for } \mathrm{Ni}^{+2} \\
8.89 \text { for } \mathrm{Cd}^{+2}\end{array}$ & [48] \\
\hline Galerina. marginata & 200 & l & 3.30 & [49] \\
\hline Sphaerotilus natans & 200 & l & 19.00 & [49] \\
\hline Streptomyces rimosus & 100 & 100 & $\begin{array}{l}9.86 \text { for } \mathrm{Cd}^{+2} \\
22.8 \text { for } \mathrm{Ni}^{2+}\end{array}$ & This study \\
\hline Grapefruit peel & 100 & 100 & $\begin{array}{l}42.09 \text { for } \mathrm{Cd}^{+2} \\
46.13 \text { for } \mathrm{Ni}^{+2}\end{array}$ & {$[50]$} \\
\hline Actinomycessp & 50 to 400 & 50 to 400 & $\begin{array}{l}4.11 \text { to } 32.63 \text { for } \mathrm{Cd}^{+2} \\
7.1 \text { to } 36.55 \text { for } \mathrm{Ni}^{+2}\end{array}$ & {$[51]$} \\
\hline Bacillus sp. & 50 to 400 & 50 to 400 & $\begin{array}{l}3.96 \text { to } 38.71 \text { for } \mathrm{Cd}^{+2} \\
4.08 \text { to } 32.8 \text { for } \mathrm{Ni}^{+2}\end{array}$ & [51] \\
\hline Marine bacteria Enterobacter cloaceae & l & 100 & $65 \%$ & {$[52,53]$} \\
\hline Marine bacteria Shewenellaoneidensis & I & 100 & $80 \%$ & {$[54]$} \\
\hline Ensifermeliloti & 100 & 1 & $85 \%$ & {$[55]$} \\
\hline Paenibacillusjamilae & l & 100 & 21 & [56] \\
\hline
\end{tabular}


The suitability of a pseudo-second-order chemical reaction for the sorption of $\mathrm{Ni}^{2+}$ and $\mathrm{Cd}^{2+}$ ions onto this biomass is apparent, as this kinetic model describes adequately the largest part of the process.

The Freundlich and Langmuir adsorption models were employed for the mathematical description of biosorption equilibrium data, regarding the biosorption of $\mathrm{Cd}^{2+}$ and $\mathrm{Ni}^{2+}$ ions onto Streptomyces rimosus. The calculated isotherm constants were used to compare the biosorption capacity for the removal of $\mathrm{Cd}^{2+}$ and $\mathrm{Ni}^{2+}$ ions. The present results demonstrate that the Langmuir model describes more accurately than the Freundlich model the adsorption equilibrium data in the examined concentration range.

The promising results obtained using this biosorbent may be therefore enhanced through the improvement of the chemical modification. For this purpose, investigations dealing with the heat-treatment of the biomass in order to improve its surface characteristics are in progress in the laboratory.

\section{NOMENCLATURE}

A : specific surface biomass $[\mathrm{m} / \mathrm{g}]$

B : constant on the affinity of adsorption sites [L/mg]

C : residual metal in solution $[\mathrm{mg} / \mathrm{L}]$

$\mathrm{C}_{b}$ : concentration of biosorbent $[\mathrm{g} / \mathrm{L}]$

$\mathrm{C}_{e}$ : concentration of equilibrium adsorption [mg/g]

$\mathrm{C}_{0}$ : initial concentration of metal [mg/L]

$\mathrm{C}_{s} \quad$ : concentration of solute in the solid particle $\left[\mathrm{g} / \mathrm{m}^{3}\right]$

$\mathrm{d}_{p} \quad$ : particle diameter $[\mathrm{m}]$

$\mathrm{D}_{u} \quad$ : internal diffusion coefficient $\left[\mathrm{m}^{2} / \mathrm{s}\right]$

$\mathrm{D}_{w}$ : internal diffusion coefficient $\left[\mathrm{m}^{2} / \mathrm{s}\right]$

$\mathrm{E}$ : removal rate of metal ions [\%]

$\mathrm{K}_{F} \quad$ : constant feature of the Freundlich equation

$\mathrm{K}_{1} \quad$ : rate constant of the first order biosorption $\left[\mathrm{s}^{-1}\right]$

$\mathrm{K}_{2} \quad$ : rate constant of second order biosorption [g/mg.s]

$\mathrm{K}_{w} \quad$ : diffusion coefficient in the solid particle [mg/g.s ${ }^{1 / 2}$ ]

n : constant feature of the Freundlich equation

$\mathrm{q}$ : biosorption capacity of biomass $[\mathrm{mg} / \mathrm{g}]$

$\mathrm{q}_{e} \quad$ : quantity of metal ions adsorbed $[\mathrm{mg} / \mathrm{g}]$

$\mathrm{q}_{m} \quad$ : maximum quantity of metal ions $[\mathrm{mg} / \mathrm{g}]$

$\mathrm{R}^{2} \quad$ : factor correlation

S : specific surface of particles adsorbed per unit volume of solution $\left[\mathrm{m}^{2} / \mathrm{m}^{3}\right]$

$\mathrm{t}$ : time for biosorption [min]

$\mathrm{v} \quad$ : volume of metal solution $[\mathrm{mL}]$

$\beta \quad$ : coefficient of external mass transfer $[\mathrm{m} / \mathrm{s}]$

$\mathrm{r}_{\text {app }} \quad$ : mass density of solid particles $\left[\mathrm{g} / \mathrm{cm}^{3}\right]$

\section{REFERENCES}

1. A. T. Ojedokun and O. Solomon Bello, Water Res. Ind., 13, 7 (2016).

2. F. E. Okeimen and V. U. Onyenkpa, Biol. Waste, 29, 11 (2000).

3. T. A. Arowolo, West Indian Med. J., 52, 63 (2004).

4. Y. H. Wu, L. Jiang, X. M. Mi, B. Li, and S. X. Feng, Korean J. Chem. Eng., 28(3), 895 (2011).

5. D. P. Mungasavalli, T. Viraraghavan and Y. C. Jin, Colloids Surf. A, 301, 214 (2007).
6. R. Kumar, N. R. Bishnoi Garima and K. Bishnoi, Chem. Eng. J., 135, 202 (2008).

7. M. J. Melgar, J. Alonso and M. A. García, Sci. Total Environ., 385, 12 (2007).

8. C. ChayTay, H. HooiLiew, Y. Chun-Yang, S. Abdul-Talib, S. Surif, A. Abdullah Suhaimi and S. Kong-Yong, Korean J. Chem. Eng., 28(3), 825 (2011).

9. Q. Yu and P. Kaewsarn, Korean J. Chem. Eng., 16 (6), 753 (1999).

10. M. I. Kefala, A. I. Zouboulis and K. A. Matis, Environ. Pollut., 104, 283 (1999).

11. P. Kaewsarn and Q. Yu, Environ. Pollution, 112, 209 (2001).

12. J. K. Park, Y. B. Jin and H. N. Chang, Biotechnol. Bioeng., 63, 116 (1999).

13. A. Selatnia, M. Z. Bakhti, A. Madani, L. Kertous and Y. Mansouri, Hydrometallurgy, 75, 11 (2004).

14. A. Selatnia, A. Madani, M. Z. Bakhti, L. Kertous, Y. Mansouri and R. Yous, Minerals Engineering, 17, 903 (2004).

15. Z. Aksu and G. Donmez, Process Biochemistry, 41, 860 (2006).

16. L. Leclerc and D. Tizerd, Microbiologie générale, Ed. Doin, Paris (1983).

17. A. Lehir, Abrégé de pharmacie galénique-formes pharmaceutiques, Ed. Masson, Paris (1981).

18. T. J. Butter, L. M. Evision, T. C. Hancock and F. C. Holland, Elution and electrolysis, $9^{\text {th }}$ forum for appl., biotechnol, Gent., 2581 (1995).

19. B. Volesky, Biosorption for the next century, Chemical Engineering Department, McGill University, 3610 University St., Montreal, Canada H3A 2B2, June 20-23 (1999).

20. I. Langmuir, J. Am. Chem. Soc., 40, 1361 (1918).

21. H. Freundlich, J. Phys. Chem., 40, 1361 (1906).

22. W. Fritz and E. U. Schlünder, Chem. Eng. Sci., 36, 731 (1981).

23. D. W. Hand, J. C. Crittenden and W. E. Thacker, J. Environ. Eng. Division, 109, 82 (1983).

24. McKay, G. Blair and H.S. Fidon, Sorption of metal ions by chitosan, In Immobilisation of ions by Bio-sorption, Ed. H. Eccles and S. Hunt, Ellis Horwood, Chichester, U.K., 59 (1986).

25. B. M. Van Vliet, W. J. Weber and H. Hozumi, Water Res., 14, 1719 (1980).

26. A. P. Mattews and W. J. Weber, Chem. Eng. Commun., 25, 157 (1984).

27. G. Mc Kay and M. J. Bino, Water Res., 22, 279 (1988).

28. M. R. L. Glover, B. D. Young and A. W. Bryson, Int. J. Miner. Process., 30, 217 (1990).

29. G. Mc Kay and S. J. Allen, in: C. H. Fuchman (Ed.), Proceedings of the Seminar on Peat as a Raw Material, Bord Na Mona Peat Research Center, Newbridge, Co Kildare, 124 (1990-1991).

30. W. J. Weber and J. C. Morris, Advances in water pollution research, Ind. Proc. Int. Conf. on water pollution Sym p, 2(162), 231 (1992).

31. McKay, G. and Victor J. P. Poots, J. Chem. Tech. Biotech., 30, 279 (1980).

32. K. Urano and H. Tachikawa, Ind. Eng. Chem. Res., 30, 1887 (1899).

33. S. B. K. Langergren, Svenska, Veternskapsakad Handlingar, 24(4), 1 (1898).

34. Y. S. Ho and G. Mac Kay, Process Biochemistry, 34, 451 (1983).

35. Z. Aksu, Sep. Purif. Technol., 21, 285 (2001).

36. E. Guibal, C. Roulph, P. L. Cloirec, Water Res., 26(8), 1139 (1992).

37. G. Sautel, C. Roulph and P. Leclerc, Cadmium biofixation by Pseu- 
domonas putidaBacteria, Récents progrès en Génie des procédés, 5, 203 (1991).

38. Fourest, E. Velosky, Applied Bioch. and Biotech., 67, 215 (1997).

39. www. Periodni. Com, Minerals Engineering 17, 903 (2004), <https:// www.google.com/search?q=tableau+periodique $>$. [Consulté le 10/ 05/2017].

40. A. Kogej and A. Pavko, Chem. Biochem. Eng. Q., 18(1), 29 (2004).

41. Y. S. Ho and G. Mckay, Proc. Bioch., 38, 1047 (2003).

42. S. Azizian, J. Colloid Interface Sci., 276, 47 (2004).

43. Y. S. Ho, J. Hazard. Mater., B136, 681 (2006).

44. N. Fiol, J. Poch and I. Villaescusa, Chemical Speciation and Bioavailability, 16, 25 (2004).

45. IH. Ceribasi and U. Yetis, Environmental Engineering Department, 06531 Ankara, TurkeyWater SA Vol. 27, No. 1 January 2001, ISSN 0378-4738.

46. Z. Filipovic-Kovacevic, Food Technol. Biotechnol., 38(3), 211 (2000).

47. D. Sidiras, F. Batzias, E. Shroeder, R. Ranjan and M. Tsapis, Chem.
Eng. J., 171, 883 (2011).

48. M. I. Ansari and A. Malik, Bioresour. Technol., 98, 3149 (2007).

49. Z. R. Holan and B. Volesky, Biotechnol. Bioengineering, 43, 1001 (1994).

50. M. Torab-Mostaedi, M. Asadollahzadeh, A. Hemmati and A. Khosravi, J. Taiwan Inst. Chem. Eng., 44, 295 (2013).

51. R. M. Karakagh, M. Chorom, H. Motamedi, Y. K. Kalkhajeh and S. Oustan, Ecohydrology Hydrobiology, 12(3), 191 (2012).

52. T. Gutierrez, D. V. Biller, T. Shimmield and D. H. Green, Biometals, 25, 1185 (2012).

53. A. Iyer, K. Mody and B. Jha, Mar. Pollut. Bull., 50, 340 (2005).

54. J. Ha, A. Gélabert, A. M. Spormann and G. E. Brown, Geochim. Cosmochim. Acta, 74, 1 (2010).

55. A. Lakzian, Asian J. Chem., 20, 6075 (2008).

56. J. A. M. Pérez, R. García-Ribera, T. Quesada, M. Aguilera, A. Ramos-Cormenzana and M. Monteoliva-Sánchez, World J. Microbiol. Biotechnol., 24, 2699 (2008). 